\author{
Marquette University \\ e-Publications@Marquette
}

2011

\title{
The Effect of Location Based Tax Incentives on Establishment Location and Employment Across Industry Sectors
}

Andrew Hanson

Marquette University, andrew.r.hanson@marquette.edu

Shawn Rohlin

Kent State University

Follow this and additional works at: https://epublications.marquette.edu/econ_fac

Part of the Economics Commons

\section{Recommended Citation}

Hanson, Andrew and Rohlin, Shawn, "The Effect of Location Based Tax Incentives on Establishment Location and Employment Across Industry Sectors" (2011). Economics Faculty Research and Publications. 200.

https://epublications.marquette.edu/econ_fac/200 
The Effect of Location Based Tax Incentives on Establishment Location and Employment Across Industry Sectors

Published in Public Finance Review, Vol. 39, No. 2 March 2011

Andrew Hanson

Department of Economics, Georgia State University
Shawn Rohlin

Department of Economics, University of Akron

\begin{abstract}
:
This paper examines the potential for location-based employment tax incentives to have a differential effect on establishment location and employment across industry sectors. We model the differential effect of the location-based federal Empowerment Zone (EZ) wage tax credit on equilibrium labor and total cost savings across industry sectors. The model guides our empirical work, as we test the effect of the program across industry sectors. Our empirical analysis shows that location based-tax incentives have a positive effect on firm location in some of the industries our model predicts and a negative effect in industries that could be crowded out.
\end{abstract}

Keywords: Tax Incentives, Industry Location, Redevelopment Policy

JEL: H25, H32, R51

We would like to thank Leslie Papke, Stuart Rosenthal, and two anonymous referees for helpful comments that improved the original manuscript. 


\section{INTRODUCTION}

Offering tax incentives to firms is part of the state and local policy maker's tool kit used to attract or maintain economic activity in a jurisdiction. The motivation behind these policies is debatable, but whether or not they succeed in attracting or maintaining economic activity within the targeted area is an empirical question. Academic research on the success of location based tax policy is mixed, with several studies finding positive effects (Papke (1994), Busso and Kline (2006), Billings (2008), Krupka and Noonan (2009)) and others finding small or no net effects (Boarnet and Bogart (1996), Bondonio and Engberg (2000), Greenbaum and Engberg (2004),

Bondonio and Greenbaum (2007), Elvery (2009), Hanson (2009), Neumark and Kolko (2010)). ${ }^{1}$

The goal of this paper is to determine if location-based tax policy has a differential effect across industry sectors. If location-based policy has a heterogeneous effect across industry sectors it could help explain some of the tension in the previous literature. The mixed results in previous findings could be driven by studying policies that are targeted to areas with different industry portfolios, or by policy design that induces industry-level churning among firms in the targeted area.

We use a simple model to show the differential impact of the location-based Empowerment Zone (EZ) tax credit across industry sectors. Our model shows varying the ability to substitute between capital and labor results in a differential effect of the EZ tax credit on the firm's equilibrium labor and total cost of production. The predictions of the model guide our empirical work as we use the assignment of the federal EZ to test the effect of the program on employment and location of firms across industry sectors that vary based on ability to substitute between capital and labor. The EZ tax incentives offer a unique opportunity to 
identify these effects, as administration of the program created a pool of applicant areas: some that received the program benefits, others that did not.

We use data from the Dun and Bradstreet survey of firms to estimate the effect of location-based tax incentives across industry types and by ability to substitute between capital and labor. Our results show that firms in industries our model predicts to have the largest reduction in total cost have an increased presence in EZ designated areas. Estimating the effect of the tax incentives across industries, we find in the short-term the retail and service sectors benefited most from the program, increasing the share of establishments in the designated area by between .16 and .30 percentage points. We find evidence that the gains from the program in some sectors were offset by losses in other sectors, as the share of establishments in the transportation and finance, insurance, and real estate industries declined by between .16 and .19 percentage points.

We also find that in the longer-term the share of employment increases in sectors that our model predicts will benefit most from the EZ tax incentives; while it declines for sectors that our model predicts will benefit least. We test the robustness of our industry-specific findings by estimating the effect of location based tax incentives across industries clustered by their ability to substitute between labor and capital and find that the empirical results fit the model prediction quite well. In addition, because of the potential for endogeneity of the EZ tax incentives, we use an instrumental variables regression where the political representation of areas in our sample determines EZ status. The results of our instrumental variables regressions largely confirm our OLS findings that the EZ tax incentives have a heterogeneous effect across industry sectors according to the degree of capital-labor substitutability.

\section{EZ WAGE TAX CREDIT: PROGRAM BACKGROUND AND MODEL}


The federal government began offering a location-based set of incentives called the Empowerment Zone (EZ) program to firms willing to operate in and hire residents of parts of designated inner city and rural areas. EZs were chosen from a group of applications made by state and local governments. Applications were accepted from areas where at least 20 percent of the population lived in poverty and 6.3 percent were unemployed (GAO, 2004). From 78 nominees (Wallace, 2004), the federal government awarded EZ status to parts of 6 cities (Atlanta, Baltimore, Chicago, Detroit, Philadelphia/Camden, New York) and 3 rural areas (Kentucky Highlands, Mississippi Delta, and the Rio Grande Valley in Texas).

The original designation began in 1995 and provided tax-preferred status for ten years ending in 2005, however Congress extended the sunset to the end of 2009 with the Community Renewal Tax Relief Act of 2000 (P.L 106-554). In addition to the six original urban EZs, the program expanded to include subsequent designations in 1998 and 2001. The EZ program is primarily a set of tax incentives claimed by employers, but also included a one-time allocation of $\$ 100$ million in the form of Social Service Block Grant funds for each designated urban area (\$40 million for rural areas). The EZ tax incentives include some small incentives to invest in capital, including: increasing the amount of property that can be immediately expensed, excluding capital gains on the sale of certain assets, and excluding capital gains on the sale of some small business stock.

The main component of the EZ program is a wage tax credit. ${ }^{2}$ An employer operating in the EZ can claim a tax credit for wages paid to an employee who resides within EZ boundaries. The EZ program has no requirement on type or tenure of the employer or employee, and no restriction on firms who relocate to the zone- any employer can claim the credit as long as they (and their employee) operate within the EZ boundaries. The amount of the credit is 20 percent of 
the first $\$ 15,000$ in wages paid, for a maximum credit of $\$ 3,000$ per employee. Qualified employees must live in census tract areas designated as EZs and perform most of their work within the EZ. The EZ wage credit can only be claimed for an employee if the employee has worked at least 90 days; there is, however, no upper bound on the tenure of an employee (IRS, 2004). Many of the nominees that did not receive an EZ designation became part of a less generous location-based incentive program called Enterprise Communities (EC) that did not include the wage tax credit. ${ }^{3}$

Previous work has modeled the effect of zone-based wage subsidies on employment outcomes, including Gravelle (1992), Papke (1993), Moore (2001) and McGuire and GaricaMila (2002). We use a simple cost minimization model where the firm minimizes total cost (TC) of production for a given level of output $(\mathrm{x})$. For illustrative purposes, we assume production follows a Cobb-Douglas function for a given level of technology (A) and two inputs capital (K) and labor (L) to illustrate how the wage subsidy can have a differential effect on firms across different industries. The price of one unit of labor is represented by $w$, and the price of one unit of capital is represented by $r$. The model is characterized by the following problem:

$$
\begin{aligned}
& \min \mathrm{TC}=w \mathrm{~L}+r \mathrm{~K} \\
& \text { s.t } \mathrm{x}=\mathrm{AK}^{\alpha} \mathrm{L}^{\beta},
\end{aligned}
$$

where we assume constant returns to scale, or that $\alpha+\beta=1$ and $\alpha>0, \beta>0$. Solving this simple cost minimization problem yields the following solutions for the optimal level of capital and labor:

$$
\begin{aligned}
& \mathrm{K}^{*}=(\alpha w / \beta r)^{\beta / \alpha+\beta}(\mathrm{x} / \mathrm{A})^{1 / \alpha+\beta} \\
& \mathrm{L}^{*}=(\beta r / \alpha w)^{\alpha / \alpha+\beta}(\mathrm{x} / \mathrm{A})^{1 / \alpha+\beta}
\end{aligned}
$$


This model can be adapted to include the EZ wage tax credit to facilitate comparison across types of firms. The EZ wage tax credit is set by statute at 20 percent of wages paid, however for flexibility of the model we include a tax credit of rate $t .^{4}$

$$
\begin{aligned}
& \min \mathrm{TC}=\mathrm{w}(1-t) \mathrm{L}+r \mathrm{~K} \\
& \text { s.t } \mathrm{x}=\mathrm{AK}^{\alpha} \mathrm{L}^{\beta}
\end{aligned}
$$

Solving the cost minimization problem with the wage tax credit yields the following solutions for the optimal level of capital and labor:

$$
\begin{aligned}
& \mathrm{K}_{\mathrm{EZ}}^{*}=(\alpha w(1-t) / \beta r)^{\beta / \alpha+\beta}(\mathrm{x} / \mathrm{A})^{1 / \alpha+\beta} \\
& \mathrm{L}_{\mathrm{EZ}}^{*}=(\beta r / \alpha w(1-t))^{\alpha / \alpha+\beta}(\mathrm{x} / \mathrm{A})^{1 / \alpha+\beta}
\end{aligned}
$$

For any positive tax credit, $t, \mathrm{~K}_{\mathrm{EZ}}{ }^{*}<\mathrm{K}^{*}$, and $\mathrm{LEZ}^{*}>\mathrm{L}^{*}$, but the degree of this difference depends on the production parameters $\alpha$ and $\beta$. In addition, total cost in equilibrium will be lower with the tax credit than without and the degree of the difference between the total cost in each case will depend on the production parameters $\alpha$ and $\beta$.

The $\alpha$ and $\beta$ parameters define the degree of substitutability between capital and labor for any given level of production. By varying $\alpha$ and $\beta$ in the production function, we can demonstrate the sensitivity to the wage tax credit of firms in industries with varying degrees of capital-labor substitutability. This simple model allows us to simulate two important effects of the tax credit across values of $\alpha$; first, the expected change in the equilibrium level of labor and second, the expected reduction in the total cost of production to the firm.

To demonstrate this effect, we simulate the introduction of a 20 percent wage tax credit (the statutory amount of the EZ wage tax credit) for a given wage, rental price of capital, level of output, and level of technology for a range of firms with different ability to substitute between labor and capital (varying the $\alpha$ and $\beta$ parameters). The results of the simulations are 
summarized by value of $\alpha$ in Figure 1. Figure 1 shows the change in equilibrium labor and the reduction in total cost that results from the introduction of a twenty percent wage tax credit across the range of values for $\alpha$.

The simulation results demonstrate the tax credit will cause the largest increase in equilibrium labor for firms in industries that can easily substitute between capital and labor (a value of $\alpha$ close to one-half). The simulation results also show that the tax credit will result in a much smaller increase in equilibrium labor by firms in industries that are less able to substitute (value of $\alpha$ close to zero or one).

Figure 1 shows that the expected reduction in total cost is driven by two factors. The first is that the wage tax credit causes substitution toward labor for firms that are able to substitute $(\alpha$ close to one-half), which reduces total costs. The second is that the wage tax credit decreases total costs more to firms that have less ability to substitute away from labor $(\alpha<.5)$, or are more labor intensive, because they use more labor in equilibrium. The simulations show that the wage tax credit will reduce total cost most for firms with a value of $\alpha$ around 0.25 .

The relationship between the reduction in total cost and the value of $\alpha$ demonstrates that the wage tax credit will be more valuable to firms that have relatively little ability to substitute away from labor. We expect that because the EZ wage tax credit is targeted based on the geographic location of the firm, firms in industries that stand to have the largest reduction in total cost would be more willing to pay to relocate to the designated EZ areas. Because the EZ designated areas are limited to a few square miles in each city, firms in industries with a smaller reduction in total cost $(\alpha>.5)$ may be outbid for land in the zone by firms that stand to gain more from the credit. Heterogeneous value of the EZ wage tax credit across industries makes it possible that the designation of the zone pushes some types of firms out of the area in favor of 
those that stand to have a larger cost reduction under the program. The potential crowding out of firms that would increase equilibrium labor the most by firms in industries that have the largest reduction in total cost does not mean that employment will not increase as a result of the subsidy. Firms in industries that have the largest reduction in total cost will also increase employment and will be more likely to enter the EZ area to take advantage of the wage tax credit. ${ }^{5}$

To map the predictions our model makes about industries with varying degrees of $\alpha$, we need a measure of this parameter. The $\alpha$ parameter in our model is the degree of substitutability between capital and labor in the production process for a given industry, which cannot be observed. Instead, we rely on an approximation to represent this parameter following Ghosal (1991). Our approximation of $\alpha$ is the equilibrium ratio of capital costs to total costs in an industry or:

$$
\alpha_{\mathrm{i}}=\mathrm{K}_{\mathrm{i}} /\left(\mathrm{L}_{\mathrm{i}}+\mathrm{K}_{\mathrm{i}}\right)
$$

where $\mathrm{L}$ is the total labor cost of production for industry $i$ and $\mathrm{K}$ is the total capital cost by production for industry $i$. Our data on labor and capital costs come from the Bureau of Economic Analysis (BEA) National Economic Accounts. ${ }^{6}$ We use private equipment and software expenses by industry as our measure of capital costs and total compensation of employees by industry as our measure of labor costs. ${ }^{7}$ Table 1 shows the value of $\alpha$ for each of the industries in our sample at the one-digit SIC industry level.

\section{TESTING THE MODEL PREDICTIONS ACROSS INDUSTRY SECTORS}

To identify the effect of the EZ tax incentives across industries we use a differencing methodology to build a counterfactual for what would have happened in the absence of the program benefits. Following Hanson (2009), our strategy is to compare how the share of firms in an industry (or employment in that industry) changes between EZ areas and the larger city 
they are a part of with EC areas and the larger city they are part of and test how the introduction of the program changes this difference- a triple difference or DDD strategy.

The two main reasons for estimating with the DDD strategy are 1) to create a reasonable counterfactual for what would have happened in EZ areas in the absence of the program, and 2) to reduce endogeneity and omitted variable bias. The EC areas make a reasonable counterfactual for what might have happened in EZ areas because they met the criteria necessary to become an EZ, but were not selected for the program. The perfect counter-factual for measuring the effect of the EZ program would be to know what would have happened in designated areas had the EZ never been assigned there. Because the EZ must be assigned to a particular area or group of areas, this is not possible. We use the EC areas to provide the best possible counter-factual for EZ assignment. By using the EC areas and differencing with the larger city we eliminate many of the concerns that arise when using simple before and after comparisons or comparisons with similar areas. Also, because EC areas were granted some of the benefits of the EZ areas, but not the wage tax credit, they can be used to isolate this effect. ${ }^{8}$

This design reduces endogeneity and omitted variables bias concerns by isolating the effect of the EZ from city fixed effects because it makes an across-time comparison. It also isolates the effect of the EZ from time-variant, city-wide effects because it makes an intra-city comparison. Thus, the error term in our regression will only include factors that change across time. The comparison group used is similar to the EZ areas but is not likely subject to negative (or positive) effects from the policy because they are made up of tracts located in different cities than the EZs. Because both the comparison and treatment groups applied for EZ designation and met the requirements for unemployment and poverty, there will be no unobservable differences caused from going through the application process or being qualified. 
By using this method, we assume that the difference between what happened in the EC areas and their larger city across time is what would have happened to the EZ areas in the absence of the program. We are not assuming that the EZ and EC areas would have grown the same; we are assuming that the difference between these areas and their surrounding cities would have grown the same in the absence of the tax incentives.

To implement the DDD strategy econometrically, we start with a full model that includes tract and city fixed effects as well as city wide trends. We then show how our DDD strategy eliminates these from our estimating equation. The full model consists of two equations, one explaining census tract level changes and the other explaining city level changes, we then difference the two equations for our estimating equation.

$$
\begin{aligned}
& Y_{\mathrm{i}, \mathrm{n}, \mathrm{t}}=\alpha+\beta E Z_{\mathrm{n}, \mathrm{t}}+\mathbf{X}_{\mathrm{i}, \mathrm{n}, \mathrm{t}}^{\prime} \delta+\theta_{\mathrm{n}}+\pi_{\mathrm{n}, \mathrm{t}}+\pi_{\mathrm{c} \supseteq \mathrm{n}, \mathrm{t}}+\mathrm{u}_{\mathrm{i}, \mathrm{n}, \mathrm{t}} \\
& Y_{\mathrm{c}, \mathrm{n}, \mathrm{t}}=\alpha+\mathbf{X}_{\mathrm{c}, \mathrm{n}, \mathrm{t}}^{\prime} \delta+\theta_{\mathrm{c}}+\pi_{\mathrm{c}, \mathrm{t}}+\mathrm{u}_{\mathrm{c}, \mathrm{n}, \mathrm{t}}
\end{aligned}
$$

where $i$ indexes a two digit SIC industry, and $n$ indexes the census tract, $\mathrm{t}$ indexes time, and c indexes a specific city. These equations also show city and tract specific time trends denoted by the $\pi$ parameters, and city and tract specific fixed effects, denoted by the $\theta$ parameters. Taking first differences in each equation eliminates the city and tract fixed effects to yield:

$$
\begin{aligned}
& \Delta Y_{\mathrm{i}, \mathrm{n}}=\alpha+\beta E Z_{\mathrm{n}}+\mathbf{X}_{\mathrm{i}, \mathrm{n}}^{\prime} \delta+\pi_{\mathrm{n}}+\pi_{\mathrm{c}}+\mathrm{u}_{\mathrm{i}, \mathrm{n}} \\
& \Delta Y_{\mathrm{c}, \mathrm{n}}=\alpha+\mathbf{X}_{\mathrm{c}, \mathrm{n}}^{\prime} \delta+\pi_{\mathrm{c}}+\mathrm{u}_{\mathrm{c}, \mathrm{n}}
\end{aligned}
$$

Notice that the tract and city fixed effects drop out after taking the difference across time, and the time subscript, $t$, is no longer necessary because we have only a before and after comparison. Taking the difference between (4) and (5) eliminates the city-specific time trend and yields the estimating equation used to determine the effect of the tax incentives on establishment location: ${ }^{9}$ 


$$
\Delta Y_{\mathrm{i}, \mathrm{n}}-\Delta Y_{\mathrm{c}, \mathrm{n}}=\alpha+\beta E Z_{\mathrm{n}}+\mathbf{X}_{\mathrm{i}, \mathrm{n}}^{\prime} \delta+\pi_{\mathrm{n}}+\mathrm{u}_{\mathrm{i}, \mathrm{n}}
$$

Where we combine the intercepts and error term for convenience and X includes city and tract level control variables. Notice that we do not observe $\pi_{\mathrm{n}}$, so that it is relegated to the error term in our regressions- we will address this issue when we estimate using instrumental variables.

The outcome variable, $\mathrm{Y}$, is either the share of total establishments in a census tract that a given industry represents or the share of total employment in a census tract that a given industry represents, and is differenced as shown above. Initially, we use data on the share of firms and employees for 1996 (one year after the EZ began) as the treatment year, and 1994 (one year before the EZ began) to test the short-term effect of the program. We also test a longer term impact of the program by using data on the share of firms and employees for 2000 as the treatment year. ${ }^{10}$

Our unit of observation is a two-digit SIC industry in a given census tract. ${ }^{11}$ Both EZ and EC areas are defined by census tract boundaries, and a given EZ or EC area consists of a group of several census tracts (the exact number varies by zone). The Census Bureau defines census tracts as statistical subdivisions of counties. Tracts average 4,000 inhabitants, ranging from 2,500 to 8,000 inhabitants. Because the primary concern in defining tracts is the population, the land area of tracts varies widely, but for densely populated urban areas they are usually quite small (many census tracts in New York city cover only a few square blocks). Both EZ and EC areas are a small part of their respective surrounding cities- between 2 and 17 percent of total land area.

The differencing method reduces the need for control variables as factors that are constant in the area will cancel out with the difference across time. Other city specific time 
trends cancel out with the difference between the EZ (or EC) area and the surrounding city. We control for a set of industry dummy variables to account for changes that may occur in specific industries that are unique to particular areas (different between the city and EZ/EC). The Dun and Bradstreet does not contain other demographic information that may be of interest as control variables, however we believe that many of these variables (education of population, racial mix of residents, income) may not be appropriate to control for as they could also be outcomes of the EZ program and therefore may bias the EZ coefficient in (6). ${ }^{12}$

The primary difference in the identification strategy presented here and previous research is the manner in which we build a counterfactual and our ability to treat zone designation as an endogenous variable. Research that examines the effect of state-level geographically targeted tax incentives includes Papke (1994), Boarnet and Bogart (1996), Bostic and Prohofsky (1996), Bondonio and Engberg (2000), Bondonio (2002), and Greenbaum and Engberg (2004) for reviews of these and other studies see Bartik (1992), Wasylenko (1997), Buss (2001), and Hanson (2009). In addition, Billings (2008) examines the possibility for the Colorado Enterprise Zone program to have a differential effect across industry sectors. Other research examines the differential outcome of location based policy across areas that differ in ways that may interact with the policy in question, such as the previous level of agglomeration (Devereux, Griffith, and Simpson (2007)).

\section{DATA}

The unit of analysis in our data is the census tract, and our data source for the number of business establishments in a census tract is the Dun and Bradstreet (D\&B) Marketplace

database. ${ }^{13}$ The data consist of the fourth quarter survey from the years 1994, 1996, and 2000. These data contain a wealth of establishment information, including employment, sales, years of 
service, the location of the establishment at the zip code level, and the two-digit Standard Industrial Classification (SIC) code. The SIC system was created by the U.S. government as a way to broadly categorize firms according to industry. The D\&B data have been used sparingly in academic literature compared to other data, as only a hand-full of previous studies use this data including Kolko and Neumark (2008), Rosenthal and Strange (2003), Audretsch and Mahmood (1995), Carlton (1983), and Evans (1987).

The D\&B data are aggregated at the zip code level. To map the zip code level data on local establishments to census tracts, we use a correspondence to match the geography of the EZ and EC designated areas. The correspondence determines what percent of each zip code lies in a given census tract and assigns that percent of zip code employment or establishments to the census tract. ${ }^{14}$ Our list of EZ and EC census tracts was obtained through personal correspondence with the Department of Housing and Urban Development, and is also partially available through that department's webpage. Each EZ or EC designated area is made of several census tracts, we treat census tracts as the unit of observation- not an entire EZ or EC, which would severely limit the number of observations in our data.

We create our dependent variable from the $\mathrm{D} \& \mathrm{~B}$ data. We measure establishment location as the share of the total number of establishments that each industry represents in a census tract. We measure industry level employment as the share of the total number of employees (employees of establishments located in the census tract) that each industry represents in a census tract. We use the share rather than the total number for two reasons. First, because the D\&B are a sample of businesses, it is possible that parts of cities are under-represented. If this is true and the under-representation is uniform across industries, then using the share of firms will mitigate under-sampling concerns. 
Second, the EZ program may cause firms in particular industries to remain in operation at the expense of those in other industries. By looking at the share of total business activity that a particular industry represents we will view this as a positive effect of the program for the industry that remains constant and a negative for a firm in an industry that ceases operation. If we were to use the number of firms as our outcome, we would only measure the negative of the firm in the industry that shuts down. The downside of using the share instead of a count is that a firm in one industry replacing a firm from another industry as a result of the program, would have an added positive effect in the replacing industry.

\section{RESULTS ACROSS INDUSTRY SECTORS}

\subsection{Establishment Location}

The top panel of Table 2 shows the short term effect of the location-based EZ tax incentives on establishment location across industry sectors. We measure this effect by the share of total establishments that each industry represents in a census tract relative to the share that it represents in the surrounding city and compare locations that received the wage tax credit (EZ areas) with those that did not (EC areas). Each row of Table 2 represents a separate regression that includes all two-digit SIC industries within the larger one-digit category. The coefficient on the EZ variable shows the marginal effect of the tax incentives on the share of firms in each industry. The constant term shows how the share of firms in each industry changed for the control group that did not receive the wage tax credit. ${ }^{15}$

The results shown in Table 2 are mostly consistent with the predictions from our simple model. The largest positive effect from the tax incentives is in the retail industry, where the share of firms increased by 0.3077 percentage points, statistically different from zero at the onepercent level. Although the coefficient seems small in magnitude it is quite large compared to 
the change in the control areas as shown by the constant term. The control areas experienced a decline in the share of firms in the retail industry of 0.4387 percentage points, statistically different from zero at the one-percent level. The change in the share of firms in the retail industry is also quite large with respect to the sample mean; the mean change in the share of retail firms was a decline of 0.01202 percentage points between 1994 and 1996.

The results in Table 2 also show a positive effect of the tax incentives in the service industry, where the share of firms increased by 0.1696 percentage points. This result is statistically different from zero at the one-percent level. The share of service industry firms in the control areas experienced a small decline, making the gain in EZ areas more meaningful. The change in the share of firms in the service industry caused by the EZ is large with respect to the mean change in our sample. The mean change in the share of service firms was an increase of 0.20307 percentage points, indicating that areas with the tax incentives increased the share of firms in the service industry by about 83 percent at the mean. The positive effect of the tax incentives on service firms locating in the EZ area is consistent with our models prediction.

The bottom panel of Table 2 presents regression results that measure the long-term effect of the tax incentives on industry location using 2000 as the treatment year. The long-term results primarily show the same pattern, in terms of the sign of the coefficients, across industry sectors as the short-term results. The largest positive effect in the long-term on the share of firms locating in the EZ areas is in the retail sector where the tax incentives were responsible for a 0.2385 percentage point increase in the share of firms, statistically significant at the five percent level. Overall, in the long-term, our results show that the EZ location based tax incentives were responsible for a shift in the composition of firms in designated areas. The shift that we see is a decline in the share of firms in the transportation industry and an increase in the share of firms in 
the retail industry. Given our estimate of $\alpha$ for these sectors, this shift confirms the prediction of our model.

The results show that the tax incentives were responsible for some industries leaving the EZ area (as measured by the change in the share of total firms). The decline experienced in EZ areas by some industries is likely the result of these firms being out-bid for land in the EZ by firms in industries that stand to have a larger reduction in total cost from the EZ program. The decline for some industries in EZ areas is perhaps best explained in the context of the standard Alonzo-Mills-Muth model. ${ }^{16}$ In this model, the economic agents (different types of firms in this case) bid for land that best suits their purpose, with highest bidder winning the use of land. Although it is beyond the scope of this paper to construct such a model, one could conceivably use the total cost reduction predicted by our simple model to adjust bids for firms in the AlonzoMills-Muth framework.

\subsection{Employment at Zone Establishments}

The top panel of Table 3 shows the short-term effect of the location-based EZ tax incentives on employment at firms across industry sectors. We measure this effect by the share of total employment at establishments that each industry represents in a census tract relative to the share that it represents in the surrounding city and compare locations that received the full complement of tax incentives with those that did not. Each row of Table 3 represents a separate regression that includes all two-digit SIC industries within the larger one-digit category. The EZ variable shows the effect of the tax incentives on the share of employment at establishments in each industry. The constant term shows how the share of employees in each industry changed for our control group that did not receive the wage tax credit. 
The results in Table 3 are not consistent with the basic prediction of the model that firms in industries with a value of $\alpha$ close to one-half will experience the largest change in employment from the tax incentives. As we explain in the modeling section, this is likely driven by the geographic nature of the program incentives. Firms in industries that benefit from the largest reduction in total cost will have the highest bids for land in the zone, which may push firms that would have substantially changed employment out of the zone.

The bottom panel of Table 3 shows regression results for the share of employees across industry sectors in the long-term, or where the treatment year is 2000. Unlike the short-term results, which produce estimates that are statistically indistinguishable from zero, the long-term results suggest a similar shifting of composition to the one we see in the share of firms in the area.

\subsection{Results by Value of $\alpha$}

Our model predicts a different effect from the tax incentives across values of $\alpha$. As a result, separating industries that have a range of $\alpha$ may produce meaningful differences in our estimates. ${ }^{17}$ To more precisely capture the heterogeneous effect on firms across values of $\alpha$ that our model predicts, we separate our data into quartiles according to the value of $\alpha$ and run separate regressions for each quartile. The breakpoints that separate our data evenly are $\alpha=0.255, \alpha=0.414$, and $\alpha=0.628$. Table 4 shows regression results by value of $\alpha$ for both the share of establishments and employment in the long and short-term.

The results presented in Table 4 confirm the predictions of the model and show the effect of the tax incentives displayed in the previous section in greater detail. These results highlight the finding that firms in industries experiencing a larger total cost reduction from the tax incentives benefit at the expense of those with a smaller cost reduction. Industry sectors with a 
value of $\alpha$ between 0.255 and 0.414 increase the share of establishments by 0.166 percentage points in the short-term (statistically significant at the one-percent level). This effect persists into the long-term with a share increase of 0.157 percentage points (statistically significant at the one-percent level).

Table 4 also shows that the gain for industries in the second quartile was at the expense of industry sectors with a value of $\alpha$ in the third and fourth quartiles. The share of these industry sectors declined by 0.117 and 0.198 percentage points (statistically significant at the one-percent level), respectively in the short-term. The loss of share for industry sectors in the third and fourth quartiles persists in the long-term, although only the fourth quartile results remain significant.

A similar pattern exists for the share of employment across industry sectors by quartile of $\alpha$. Industries in the second quartile increase the share of employment at the expense of those in the third and fourth quartiles. In the short-term, industries in the second quartile increase the share of employment by almost a full percentage point (0.952) statistically significant at the onepercent level. Industries in the third quartile show a decline of 0.327 percentage points, statistically significant at the ten percent level. Industries in the fourth quartile show the largest reduction in the share of employment at 0.499 , statistically significant at the ten percent level.

The pattern persists in the long-term as industry sectors in the second quartile increase the share of employment by more than a full percentage point. The long-term gain for industry sectors in the second quartile remains at the expense of industry sectors in the third and fourth quartile. Industry sectors with a value of $\alpha$ between 0.414 and 0.628 show a 0.738 percentage point decline in the share of employment, while those with an $\alpha$ value over 0.628 decline by 0.598 percentage points. 


\subsection{Instrumental Variables Results}

Our OLS results show a heterogeneous effect of location-based tax incentives across industry sectors and by level of capital-labor substitutability. The OLS results, may however, be biased toward finding an effect of the tax incentives. As we explain in the identification section, our differencing strategy leaves out any census-tract specific variables that change over time. This omission could bias our results if these omitted variables are correlated with the designation of EZ areas. Selection of EZ areas seems to have been at least partially based on choosing areas that would have been economically successful even in the absence of the EZ tax incentives, see Hanson (2009) for a full explanation of this issue.

To deal with the potential for bias caused by the selection of EZ areas we follow the instrumental variable strategy outlined by Hanson (2009) and use congressional representation of areas that applied for EZ designation to explain designation of the program. We use congressional representation on the U.S. House of Representatives Ways and Means Committee as our instrument for EZ designation. This choice is based on work by Wallace (2004) that shows this committee (and no others) to be a significant determinant of EZ designation. We use both a dummy variable for representation on the Ways and Means committee as well as the number of years that the member has served on the committee as our instruments. ${ }^{18}$

The first-stage instrumental variables results are shown in Table 5. These results suggest that the correlation between our instruments and the designation of an area for the EZ tax incentives is quite strong. The Ways and Means member dummy variable by itself (column 1) is both positive and significant at the one-percent level and easily passes the instrument F-test. The number of terms that the Representative served on the Ways and Means committee is even stronger and also easily passes the instrument F-test. Columns 3 and 4 show results using both 
instruments together. Again the correlation between the instruments is strong and the instruments easily pass the joint F-test. ${ }^{19}$

As a further check on the validity of our instruments we run several diagnostic tests. We test the over-identification restrictions (because we use two instruments), this test of the SargonHansen J-statistic fails to reject the null hypothesis that instruments are valid (p-value of 0.986). We test for under-identification using the Kleibergen-Paap LM-test, and easily reject the null hypothesis (p-value of 0.00 ) that our matrix is not of full column rank- a conclusion that supports the model as being identified. Furthermore, our instruments are far outside of the range of the Stock-Yogo (2005) critical values (F-statistic of over 3100, when only 19 is required) that would suggest a weak identification problem- i.e. our instruments are strong enough to be considered strongly correlated with EZ assignment.

On balance, the second-stage instrumental variables results confirm the results in Tables $2-4$, although some of the industry sector effects change. Table 6 presents the short-term results on industry location using IV. The only major difference between the short-term IV and the OLS is that the IV results suggest the manufacturing sector increased the share of firms locating in EZ areas, which is counter to what our model predicts given the relatively high value of $\alpha$ for that sector. The strong positive and significant effect on the share of firms locating in EZ areas in the retail sector remains.

The long-term effects on establishment location, shown in Table 6, do not match as well with the OLS results. The primary difference is the estimated effect on firms in the retail industry sector. The second-stage results for the share of employment across industry sectors are more consistent with the OLS results. Table 7 shows that the IV estimation suggests a negative change for the retail industry, although this result is not statistically significant. The sign on the 
manufacturing sector changes to positive and this result is statistically different from zero at the five-percent level. In addition, the IV results are somewhat more precise as the negative effect in the transportation industry is statistically significant at the ten-percent level.

As with the OLS estimates, we divide our industries up by value of $\alpha$ and run separate instrumental variables regressions for each quartile. Table 8 shows the instrumental variables results by value of $\alpha$ for both the share of establishments (our measure of location) and the share of employment in the short and long-term. Overall, these results match quite well with our OLS results and in many cases show a stronger effect of the tax incentives.

The IV results remove any selection bias from the estimation and are closer to being a purely causal effect of the program. Although it is difficult to judge why some of the coefficients for particular industries or values of alpha are different, the methods on balance produce similar results. Murray (2006) suggests that the relative bias of the estimates (IV/OLS) will be equal to the number of instruments divided by the product of the number of observations and the first stage R-squared. This comparison method suggests that for each instrument and for the case where we use both instruments simultaneously, the IV results are less biased than the OLS.

\section{CONCLUSION}

The model that we outline in this paper makes the prediction that the EZ tax credit will have a heterogeneous effect on the quantity of labor used and the resulting reduction in total cost for firms that claim it. Tying the wage credit to the location of a firm means firms that benefit more from this type of incentive should out-bid firms that benefit less (in the form of reduced total costs). Our empirical work demonstrates that our simple model goes a long way in predicting the differential effect of a location based tax incentive across industry sectors. 
Our findings show that the federal Empowerment Zone tax incentive program is responsible for altering the industrial mix in areas where it is available. Particularly, our estimation results show that firms in industries that our model predicts to have the largest reduction in total cost have an increased presence in EZ designated areas. This increase comes at the expense of industries that benefit least from the program. We find in the short-term, the retail and service sectors benefited most from the program, increasing the share of establishments in the designated area by between .16 and .30 percentage points. These gains are offset by the transportation and finance, insurance, and real estate industries, which experienced a decline in the share of establishments by between .16 and .19 percentage points.

The heterogeneous effect across industry sectors that we demonstrate in this paper helps explain some of the tension in the previous literature. Our research suggests that if a particular policy is targeted to an area with an existing base of firms that will benefit from the policy it may be more effective. It also suggests that small or zero effects of particular policy could be driven by churning at the industry level.

Understanding the relationship between location-based policy and industry sectors can help guide policy makers to choose a policy that meets their goals. The industry level affects we demonstrate are not a goal of the EZ program; however, they are an important consequence. Policy makers should be aware of the potential for industry level churning and other unintended consequences of location-based tax incentives when crafting policy. 
${ }^{1}$ These papers cover a range of programs including several different state-level geographically targeted tax incentives, often called Enterprise Zones, and papers that study the Federal Empowerment Zone program. The common theme among these programs is that they define who receives benefits based on geographic location, often within an otherwise homogenous taxing jurisdiction (like a city or county for example). The actual benefits afforded under these programs differ substantially and may not include the same benefits as the Federal Empowerment Zone program discussed here. See Bondonio and Engberg (2000) and Bondonio and Greenbaum (2007) for papers that describe and classify several state-level Enterprise Zone programs.

${ }^{2}$ According to the U.S Government Accountability Office (1999), the wage tax credit is the most-used tax incentive by zone businesses; the IRS does not report claims for any of the other zone-related incentives besides the zone facility bonds.

${ }^{3}$ The Boston, Oakland, Houston and Kansas City nominees were designated as Enhanced Enterprise Communities (EEC). EEC status gave these communities a more generous allocation of grant funds than the standard Enterprise Communities. Two nominees, Cleveland and Los Angeles, were awarded the status of Supplemental Empowerment Zone (SEZ) (GAO, 2004), which did not allow for all of the tax benefits of regular EZs, but included more generous grants than regular EZs.

${ }^{4}$ For simplicity, we assume that the gross wage paid is not a function of the tax credit. This is equivalent to assuming that the economic incidence of the wage tax credit falls entirely on producers.

${ }^{5}$ Recall that the EZ program has no restriction on the type or tenure of the firm in the EZ area. Any firm can claim the benefits as long as they operate in the EZ and hire employees who live in the EZ area. This means that firms that are new to the area are available for benefits regardless of where they relocate from.

${ }^{6}$ We use BEA data from 2000 at the industry level according to the North American Industry Classification System (NAICS) classification of industries. Because the NAICS industry classification does not match exactly with SIC industry classification, we use a correspondence from Census to match them. The NAICS to SIC correspondence can be found on-line at: http://www.census.gov/epcd/www/naicstab.htm. 
${ }^{7}$ Equipment is valued as the current value net of depreciation. See www.bea.gov, for a description of construction of the private fixed assets. This includes how the BEA estimates depreciation, service lives, and declining balance rates.

${ }^{8}$ The EZ wage credit is by far the most used incentive in the EZ program in terms of both number of claimants and dollars claimed (GAO, 1999), in fact there are so few claims on the other tax incentives that the IRS does not bother to report on them $(\mathrm{GAO}, 1999)$. EZ areas also received a larger one-time allocation of Social Service Block Grant funds at the start of the program than EC areas (\$100 million and \$3 million, respectively). These funds were limited to use for day care for children, employment services, counseling, legal services, transportation, education, and substance abuse recovery. Because we cannot truly separate the larger Block Grant funding from the wage tax credit, our coefficients should be viewed literally as the joint effect of these two benefits.

${ }^{9}$ Note that $\Delta \mathrm{Y}_{\mathrm{i}, \mathrm{n}}-\Delta \mathrm{Y}_{\mathrm{c}, \mathrm{n}}=\left(\mathrm{Y}_{\mathrm{i}, \mathrm{n}}-\mathrm{Y}_{\mathrm{i}, \text { city }}\right)_{1996}-\left(\mathrm{Y}_{\mathrm{i}, \mathrm{n}}-\mathrm{Y}_{\mathrm{i}, \text { city }}\right)_{1994}$

${ }^{10}$ We use the year 2000 as our long-term treatment effect year because the EZ program underwent substantial expansion in 2001. At that time, some of the original EC areas (our control group) were awarded EZ status. We do not use the expansion of the program in our identification strategy because the application process and choice of new zones is not as clearly defined as it is for the original designation.

${ }^{11}$ We exclude all rural EZ areas from our analysis as they are in extremely different (both demographically and economically) areas of the country. In addition, the rural EZ areas are made up of relatively few census tracts, so they would not provide many additional observations.

${ }^{12}$ See Angrist and Pischke (2009) for a particularly lucid description of this problem.

${ }^{13}$ Although the D\&B does not contain all business activity in the U. S., the omissions from the data are considered sufficiently random so that the data is representative of the spatial distribution of the business activity (Holmes, 1998 and Rosenthal and Strange, 2003).

${ }^{14}$ To use this correspondence, we assume that the amount of business activity in a zip code is distributed randomly across the zip code. This is a standard assumption in the literature and is documented in well citied papers, such as Holmes (1998) and Rosenthal and Strange (2003).

${ }^{15}$ Our interpretation of the constant as the share of firms in each industry in control cities (the expected value of the dependent variable given presence in a control area before treatment) is straightforward from the Difference-in- 
Difference model. See Madrian (1994) or Card and Krueger (1994) for prominent examples, see Angrist and Pishke (2009) for a full explanation of the interpretation of coefficients in a Difference-in-Difference model.

${ }^{16}$ See O’Sullivan (2009) pages 121-145 for an elementary treatment of the standard Alonzo-Mills-Muth model and corresponding bids for land among various firms.

${ }^{17}$ The value of $\alpha$ can differ substantially among two-digit industries within the one-digit category. For example, in the broad one-digit service industry, which we assign a value of $\alpha$ at 0.275 , the range of two-digit industry values of $\alpha$ range from a low of 0.09 (legal services) to a high of 0.42 (amusement and recreation services).

${ }^{18}$ The idea of using politically related variables as instruments is not unique to our research. Knight (2002) uses several politically related variables as instruments, including committee assignment of federal Representatives, for federal grant spending to determine crowd out effects on state and local spending. Other studies, including Poterba (1994), Levitt (1997), and Kubik and Moran (2003) use the exogenous cycle of elections to explain politically motivated action.

${ }^{19}$ The first stage instrument results are sensitive to assumptions about the spatial correlation of the error term. If we cluster the standard errors in the first stage by city, we lose quite a bit of statistical power because the city level variation is lost. 


\section{REFERENCES}

Angrist, Joshua, and Jörn-Steffen Pischke. 2009. Mostly Harmless Econometrics: An Empiricist's Companion. Princeton, New Jersey: Princeton University Press.

Audretsch, David, and Talat Mahmood. 1995. New firm survival: New results using a hazard function. Review of Economics and Statistics 77 (1): 97-103.

Bartik, Timothy. 1992. The effects of state and local taxes on economic development: A review of recent research. Economic Development Quarterly 6 (1): 102-111.

Billings, Stephen. 2008. Do Enterprise Zones Work? An Analysis at the Borders. Public Finance Review 37 (1): 68-93.

Binger, Brian, and Elizabeth Hoffman. 1998. Microeconomics with Calculus. Addison-Wesley Educational Publishers.

Boarnet, Marlon, and William Bogart. 1996. Enterprise Zones and Employment: Evidence from New Jersey. Journal of Urban Economics 40 (2): 198-215.

Bondonio, Daniele. 2002. Evaluating decentralized policies: a method to compare the performance of economic development programmes across different regions or states, Evaluation 8 (1): 101-124.

Bondonio, Daniele, and Robert Greenbaum. 2007. Do Tax Incentives Effect Local Economic Growth? What Mean Impacts Miss in the Analysis of Enterprise Zone Policies. Regional Science and Urban Economics 37 (1): 121-136.

Bondonio Daniele, and John Engberg. 2000. Enterprise Zones and local employment: evidence from the states' programs. Regional Science and Urban Economics 30 (5): 519-549.

Bostic, Raphael, and Allen Prohofsky. 2006. Enterprise Zones and Individual Welfare: A Case Study of California. Journal of Regional Science 46 (2): 175-203.

Buss, Terry. 2001. The Effect of State Tax Incentives on Economic Growth and Firm Location Decisions: An Overview of the Literature. Economic Development Quarterly 15 (1): 90-105.

Busso, Matias, and Patrick Kline. 2006. Do Local Economic Development Programs Work? Evidence from the Federal Empowerment Zone Program. Unpublished Manuscript.

Card, David, and Alan Krueger. 1994. Minimum Wages and Employment: A Case Study of the Fast Food Industry in New Jersey and Pennsylvania. American Economic Review 84 (4): $772-$ 84. 
Carlton, Dennis. 1983. The Location and Employment Choices of New Firms: An Econometric Model with Discrete and Continuous Endogenous Variables. Review of Economics and Statistics 65 (3): 440-49.

Devereux, Michael, Rachel Griffith, and Helen Simpson. 2007. Establishment location decisions, regional grants, and agglomeration externalities. Journal of Public Economics 91 (34): 413-435.

Elvery, Joel. 2009. The Impact of Enterprise Zones on Resident Employment: An Evaluation of the Enterprise Zone Programs of California and Florida. Economic Development Quarterly 23 (1): 44-59.

Evans, David. 1987. Tests of alternative theories of firm growth. Journal of Political Economy 95 (4): 657-674.

Ghosal, Vivek. 1991. Demand uncertainty and the capital-labor ratio: Evidence from the U.S. manufacturing sector. Review of Economics and Statistics 73 (1): 157-160.

Gravelle, Jane. 1992. Enterprise Zones: The Design of Tax Incentives, CRS Report for Congress, Congressional Research Service.

Greenbaum, Robert, and John Engberg. 2004. The Impact of State Enterprise Zones on Urban Manufacturing Establishments. Journal of Policy Analysis and Management 23 (2): 315-339

Hanson, Andrew. 2009. Local Employment, Poverty, and Property Value Effects of Geographically-Targeted Tax Incentives: An Instrumental Variables Approach. Regional Science and Urban Economics 39(6): 721-731.

Holmes, Thomas. 1998. The effect of state policies on the location of manufacturing: Evidence from state borders. Journal of Political Economy 106 (4): 667-705.

Internal Revenue Service, Department of the Treasury. 2004. Publication 954: Tax Incentives for Distressed Communities. http://www.irs.gov/pub/irs-pdf/p954.pdf.

Knight, Brian. 2002. Endogenous Federal Grants and Crowd-Out of State Government Spending: Theory and Evidence from the Federal Highway Aid Program. American Economic Review 92 (1): 71-92.

Kolko, Jed, and David Neumark. 2008. Changes in the Location and Employment of Ownership: Evidence from California. Journal of Regional Science 48 (4): 717-743.

Krupka, Douglas, and Douglas Noonan. 2009. Empowerment Zones, Neighborhood Change and Owner Occupied Housing. Regional Science and Urban Economics 39 (4): 386-396.

Kubik, Jeffrey, and John Moran. 2003. Lethal Elections: Gubernatorial Politics and the Timing of Executions. Journal of Law and Economics 46 (1): 1-26. 
Levitt, Steven. 1997. Using Electoral Cycles in Police Hiring to Estimate the Effect of Police on Crime. American Economic Review 87 (3): 270-290.

Madrian, Brigitte. 1994. Employment Based Health Insurance and Job Mobility: Is There Evidence of Job-Lock? Quarterly Journal of Economics 109 (1): 27-54.

McGuire, Therese, and Teresa Garcia-Mila. 2002. Tax Incentives and the City. In BrookingsWharton Papers on Urban Affairs, William Gale and Janet Rothenberg Pack eds., 95-114. Washington, DC: Brookings Institution Press.

Moore, William. 2001. The Economic Effect of Enterprise Zone Programs on Local Labor Markets: A Theoretical Perspective. Ph.D. Dissertation, Syracuse University.

Neumark, David, and Jed Kolko. 2010. Do Enterprise Zones Create Jobs? Evidence from California's Enterprise Zone Program. Journal of Urban Economics 68 (1): 1-19.

O’Sullivan, Arthur. 2009. Urban Economics. New York, NY: McGraw-Hill Irwin Press.

Murray, Michael. 2006. Avoiding Invalid Instruments and Coping with Weak Instruments. Journal of Economic Perspectives 20 (4): 111-132.

Papke, Leslie. 1994. Tax policy and urban development: Evidence from the Indiana enterprise zone program. Journal of Public Economics 54 (1): 37-49.

Papke, Leslie. 1993. What Do We Know About Enterprise Zones? In Tax Policy and the Economy (Volume 7), James Poterba ed., 37-72. Cambridge, MA: MIT Press.

Poterba, James. 1994. State Responses to Fiscal Crises: The Effects of Budgetary Institutions and Politics. Journal of Political Economy 102 (4): 799-821.

Rosenthal, Stuart, and William Strange. 2003. Geography, industrial organization and Agglomeration. Review of Economics and Statistics 85 (2): 377-393.

Stock, James, and Motohiro Yogo. 2005. Testing for weak instruments in linear IV regression. In Identification and Inference for Econometric Models: Essays in Honor of Thomas Rothenberg, Donald Andrews and James Stock eds., 80-108. Cambridge, MA: Cambridge University Press.

U.S. Government Accountability Office. 1999. Businesses' Use of Empowerment Zone Tax Incentives: Report to Congressional Requesters. GAO/RCED-99-253, Washington, D.C.

U.S. Government Accountability Office. 2004. Federal Revitalization Programs Are Being Implemented, but Data on the Use of Tax Benefits Are Limited: Report to Congressional Committees. GAO-04-306, Washington, D.C. 
Wallace, Marc. 2004. Congressional Considerations and Urban Characteristics in the Selection of Empowerment Zones and Enterprise Communities. Journal of Urban Affairs 26 (5): 593-609.

Wasylenko, Michael. 1997. Taxation and economic development. New England Economic Review March/April: 37-52. 
Andrew Hanson is an assistant professor in the department of economics at Georgia State University. He received his doctorate in economics from Syracuse University. Much of his work has focused on evaluating the effect of geographically targeted tax incentives. He has also worked on research related to tax incidence, housing markets.

Shawn Rohlin is an assistant professor in economics at The University of Akron. He received his doctorate degree in economics from Syracuse University. His research focuses on how government policies impact local economic outcomes, such as business location decisions and agglomeration economies. 
Table 1: Value of $\alpha$ Parameter by Industry at One Digit SIC

\begin{tabular}{|c|c|c|}
\hline \multicolumn{3}{|c|}{ Level } \\
\hline Industry & $\underline{\text { SIC Codes }}$ & Value of $\alpha$ \\
\hline Retail & $52-59$ & 0.255 \\
\hline Services & $70-89$ & 0.275 \\
\hline Construction & $15-17$ & 0.293 \\
\hline Wholesale & $50-51$ & 0.409 \\
\hline FIRE $^{a}$ & $60-67$ & 0.477 \\
\hline Manufacturing & $20-39$ & 0.532 \\
\hline Transportation & $40-49$ & 0.656 \\
\hline Mining & $10-14$ & 0.737 \\
\hline Agriculture & $1-9$ & 0.813 \\
\hline
\end{tabular}


Table 2: Effect of Tax Incentives on Establishment Location, Standard Errors Clustered at the City Level Shown in Parenthesis

\begin{tabular}{|c|c|c|c|c|c|c|c|}
\hline $\begin{array}{l}\text { Short } \\
\text { Term }\end{array}$ & Construction & Manufacturing & Transportation & Wholesale & Retail & FIRE & Service \\
\hline \multirow[t]{2}{*}{ Constant } & -0.001777 & $-0.000438^{* *}$ & -0.000697 & $-0.00272^{\star * *}$ & $-0.00438^{* * *}$ & $0.001568^{* * *}$ & -0.000173 \\
\hline & $(0.001123)$ & $(0.000185)$ & $(0.000521)$ & $(0.000982)$ & $(0.00139)$ & $(0.000573)$ & $(0.000291)$ \\
\hline \multirow[t]{2}{*}{ EZ } & -0.000328 & -0.000121 & $-0.001916^{* * *}$ & 0.000525 & $0.003077^{* * *}$ & $-0.00391^{* * *}$ & $0.001696^{* * *}$ \\
\hline & $(0.001664)$ & $(0.000312)$ & (0.000488) & $(0.002646)$ & $(0.000909)$ & (0.00083) & $(0.000677)$ \\
\hline $\mathrm{N}$ & 3,993 & 26,620 & 11,979 & 2,662 & 10,648 & 9,317 & 18,634 \\
\hline$R^{2}$ & 0.03 & 0.02 & 0.03 & 0.01 & 0.04 & 0.04 & 0.1 \\
\hline \multicolumn{8}{|l|}{$\begin{array}{l}\text { Long } \\
\text { Term }\end{array}$} \\
\hline \multirow[t]{2}{*}{ Constant } & -0.00177 & $-0.00053^{* *}$ & -0.000335 & -0.001884 & $-0.00456^{\star * *}$ & $0.00082^{*}$ & -0.000023 \\
\hline & $(0.001116)$ & $(0.000232)$ & $(0.000566)$ & $(0.001196)$ & $(0.001198)$ & $(0.000462)$ & $(0.000282)$ \\
\hline \multirow[t]{2}{*}{ EZ } & 0.0004 & 0.000044 & $-0.002107^{* * *}$ & 0.001484 & $0.002385^{\star *}$ & -0.001624 & 0.000316 \\
\hline & $(0.001624)$ & $(0.000286)$ & $(0.000594)$ & $(0.002545)$ & $(0.000915)$ & $(0.00165)$ & $(0.000903)$ \\
\hline $\mathrm{N}$ & 3,993 & 26,620 & 11,979 & 2,662 & 10,648 & 9,317 & 18,634 \\
\hline $\mathrm{R}^{2}$ & 0.04 & 0.02 & 0.03 & 0.01 & 0.03 & 0.05 & 0.13 \\
\hline
\end{tabular}

${ }^{* * *}$ indicates statistically significant at 1 percent level, ${ }^{* *}$ at 5 percent level, ${ }^{*}$ at 10 percent level.

Notes:

(a) The pre-treatment year is 1994, the treatment year is 1996 .

(b) Unit of observation is the two digit SIC industry at the census tract level of geography.

(c) Data on the number of firms in a given industry is from the Dunn \& Bradstreet survey and is differenced to reflect our identification strategy.

(d) The EZ variable represents designation of the federal Empowerment Zone wage tax credit at the census tract level, the coefficient on this variable reflects the effect of this tax incentive on the share of business establishments that locate in the area relative to the surrounding city compared to areas that applied for the EZ designation but were denied relative to their respective surrounding city.

(e) The number of observations differs across industries because they have a different number of two-digit industries within the one-digit class. All census tracts are represented in each industry classification. 
Table 3: Effect of Tax Incentives on Employment at Zone Establishments, Standard Errors Clustered at the City Level Shown in Parenthesis

\begin{tabular}{|c|c|c|c|c|c|c|c|}
\hline $\begin{array}{l}\text { Short } \\
\text { Term }\end{array}$ & Construction & Manufacturing & Transportation & Wholesale & Retail & FIRE & Service \\
\hline Constant & $\begin{array}{l}-0.00523^{* * *} \\
(0.001269)\end{array}$ & $\begin{array}{l}-0.001859^{*} \\
(0.001015)\end{array}$ & $\begin{array}{c}0.000318 \\
(0.002115)\end{array}$ & $\begin{array}{l}-0.001298 \\
(0.001731)\end{array}$ & $\begin{array}{l}-0.002169 \\
(0.001413)\end{array}$ & $\begin{array}{l}0.001969^{\star *} \\
(0.000951)\end{array}$ & $\begin{array}{l}-0.000151 \\
(0.000252)\end{array}$ \\
\hline$E Z$ & $\begin{array}{l}-0.000645 \\
(0.00111)\end{array}$ & $\begin{array}{l}-0.000039 \\
(0.000582)\end{array}$ & $\begin{array}{l}-0.003881 \\
(0.002841)\end{array}$ & $\begin{array}{l}-0.001828 \\
(0.005011)\end{array}$ & $\begin{array}{c}0.001073 \\
(0.001135)\end{array}$ & $\begin{array}{c}0.001748 \\
(0.003035)\end{array}$ & $\begin{array}{c}0.00025 \\
(0.001021)\end{array}$ \\
\hline $\begin{array}{c}\mathrm{N} \\
\mathrm{R}^{2} \\
\\
\text { Long } \\
\text { Term }\end{array}$ & $\begin{array}{c}3,993 \\
0.02\end{array}$ & $\begin{array}{c}26,620 \\
0.01\end{array}$ & $\begin{array}{c}11,979 \\
0.01\end{array}$ & $\begin{array}{c}2,662 \\
0.01\end{array}$ & $\begin{array}{c}10,648 \\
0.01\end{array}$ & $\begin{array}{c}9,317 \\
0.01\end{array}$ & $\begin{array}{c}18,634 \\
0.01\end{array}$ \\
\hline Constant & $\begin{array}{c}-0.00569^{* * *} \\
(0.00151)\end{array}$ & $\begin{array}{c}-0.001976^{* *} \\
(0.001009)\end{array}$ & $\begin{array}{c}0.001235 \\
(0.002173)\end{array}$ & $\begin{array}{c}0.000673 \\
(0.002188)\end{array}$ & $\begin{array}{l}-0.002595 \\
(0.001634)\end{array}$ & $\begin{array}{c}0.000624 \\
(0.001165)\end{array}$ & $\begin{array}{l}-0.000305 \\
(0.000293)\end{array}$ \\
\hline$E Z$ & $\begin{array}{c}0.000333 \\
(0.001085)\end{array}$ & $\begin{array}{c}-0.00009 \\
(0.000606)\end{array}$ & $\begin{array}{l}-0.005069^{\star *} \\
(0.002414)\end{array}$ & $\begin{array}{l}-0.000324 \\
(0.004725)\end{array}$ & $\begin{array}{c}0.002633^{* * *} \\
(0.000803)\end{array}$ & $\begin{array}{c}0.00037 \\
(0.002372)\end{array}$ & $\begin{array}{c}0.00147 \\
(0.001261)\end{array}$ \\
\hline $\mathrm{N}$ & 3,993 & 26,620 & 11,979 & 2,662 & 10,648 & 9,317 & 18,634 \\
\hline $\mathrm{R}^{2}$ & 0.03 & 0.01 & 0.01 & 0.02 & 0.01 & 0.02 & 0.01 \\
\hline
\end{tabular}

Notes:

(a) The pre-treatment year is 1994, the treatment year is 1996 .

(b) Unit of observation is the two digit SIC industry at the census tract level of geography.

(c) Data on the employment at establishments in a given industry is from the Dunn \& Bradstreet survey and is differenced to reflect our identification strategy.

(d) The EZ variable represents designation of the federal Empowerment Zone wage tax credit at the census tract level, the coefficient on this variable reflects the effect of this tax incentive on the share of business establishments that locate in the area relative to the surrounding city compared to areas that applied for the EZ designation but were denied relative to their respective surrounding city.

(e) The number of observations differs across industries because they have a different number of two-digit industries within the one-digit class. All census tracts are represented in each industry classification. 
Table 4: Effect of Tax Incentives by Quartile Value of $\alpha$, Standard Errors Clustered at the City Level Shown in Parenthesis

\begin{tabular}{|c|c|c|c|c|c|c|}
\hline \multirow{3}{*}{ Share of Establishments } & \multicolumn{2}{|c|}{ Short Term (1994-1996) } & \multicolumn{2}{|c|}{ Long Term (1994-2000) } & \multirow[b]{2}{*}{ Industries } & \multirow[b]{2}{*}{$\underline{N}$} \\
\hline & $\underline{\text { Constant }}$ & $\underline{E Z}$ & Constant & $\underline{E Z}$ & & \\
\hline & & & & & & \\
\hline \multirow[t]{2}{*}{ Labor Intensive $(\alpha<0.255)$} & $0.0009338^{\star \star *}$ & $0.0015695^{\star *}$ & $0.0009761^{* * *}$ & 0.0005498 & 19 & 25,289 \\
\hline & $(0.0002448)$ & $(0.0007107)$ & $(0.0002506)$ & $(0.0009263)$ & & \\
\hline \multirow[t]{2}{*}{$0.255 \leq \alpha<0.414$} & $-0.000917^{* \star *}$ & $0.0016673^{\star * *}$ & $-0.000798^{* * *}$ & $0.0015799^{* * *}$ & 18 & 23,958 \\
\hline & $(0.0002532)$ & $(0.0005167)$ & $(0.0002285)$ & $(0.0003603)$ & & \\
\hline \multirow[t]{2}{*}{$0.414 \leq \alpha<0.628$} & -0.0001667 & $-0.001176^{\star * *}$ & -0.0001912 & -0.0001547 & 17 & 22,627 \\
\hline & $(0.0001539)$ & $(0.0002256)$ & $(0.0001277)$ & $(0.0008395)$ & & \\
\hline \multirow[t]{2}{*}{ Capital Intensive $(\alpha \geq 0.628)$} & 0.0000154 & $-0.001988^{\star * *}$ & $-0.0001119^{*}$ & $-0.001931^{* \star *}$ & 19 & 25,289 \\
\hline & $(0.0000709)$ & $(0.0004013)$ & $(0.0000576)$ & $(0.0003942)$ & & \\
\hline \multicolumn{7}{|l|}{ Share of Employment } \\
\hline \multirow[t]{2}{*}{ Labor Intensive $(\alpha<0.255)$} & 0.0010014 & 0.0007788 & -0.000256 & 0.0039061 & 19 & 25,289 \\
\hline & $(0.0011724)$ & $(0.0018374)$ & $(0.0012971)$ & $(0.002752)$ & & \\
\hline \multirow[t]{2}{*}{$0.255 \leq \alpha<0.414$} & -0.0012115 & $0.0095212^{* * *}$ & 0.0001686 & $0.0108422^{\star \star \star}$ & 18 & 23,958 \\
\hline & $(0.0012353)$ & $(0.0035501)$ & $(0.0012554)$ & $(0.0039071)$ & & \\
\hline \multirow[t]{2}{*}{$0.414 \leq \alpha<0.628$} & -0.0001707 & $-0.0032705^{*}$ & 0.0009908 & $-0.007387^{* * *}$ & 17 & 22,627 \\
\hline & $(0.001112)$ & $(0.002542)$ & $(0.0011834)$ & $(0.0023127)$ & & \\
\hline \multirow[t]{2}{*}{ Capital Intensive $(\alpha \geq 0.628)$} & 0.0005217 & $-0.0049987^{*}$ & 0.0001249 & $-0.0059877^{\star *}$ & 19 & 25,289 \\
\hline & $(0.0006873)$ & $(0.003074)$ & $(0.000723)$ & $(0.0026487)$ & & \\
\hline
\end{tabular}
Notes:

(a) The pre-treatment year is 1994; the treatment year for the short term is 1996 and is 2000 for the long term.

(b) Unit of observation is the two digit SIC industry at the census tract level of geography.

(c) Data on the share of firms in a given industry is from the Dunn \& Bradstreet survey and is differenced as shown in equation 1 to reflect our identification strategy.

(d) The EZ variable represents designation of the federal Empowerment Zone wage tax credit at the census tract level, the coefficient on this variable reflects the effect of this tax incentive on the share of business establishments that locate in the area relative to the surrounding city compared to areas that applied for the EZ designation but were denied relative to their respective surrounding city. 
Table 5: First Stage IV: Dependent Variable is EZ Designation, Standard Errors Shown in Parenthesis

\begin{tabular}{|c|c|c|c|c|}
\hline & (1) & (2) & (3) & (4) \\
\hline Ways and Means Member & $\begin{array}{c}0.1416^{\star * *} \\
(0.0033)\end{array}$ & & $\begin{array}{c}-0.2589^{* * *} \\
(.0061)\end{array}$ & $\begin{array}{c}-0.2589^{* * *} \\
(.0061)\end{array}$ \\
\hline Number of Terms on Committee & & $\begin{array}{c}0.0224^{* * *} \\
(.0004)\end{array}$ & $\begin{array}{c}0.0445^{\star * *} \\
(.0006)\end{array}$ & $\begin{array}{c}0.0445^{\star * *} \\
(.0006)\end{array}$ \\
\hline Constant & $\begin{array}{c}0.1826 \\
(0.0013)\end{array}$ & $\begin{array}{c}0.1727 \\
(0.0013)\end{array}$ & $\begin{array}{c}0.1826 \\
(0.0013)\end{array}$ & $\begin{array}{c}0.1826 \\
(0.0109)\end{array}$ \\
\hline Industry fixed effects & no & no & no & yes \\
\hline $\mathrm{N}$ & 105149 & 105149 & 105149 & 105149 \\
\hline $\mathrm{R}^{2}$ & 0.0169 & 0.0443 & 0.0573 & 0.0573 \\
\hline Instrument F-test $(1,105147)$ & 1804.36 & 4870.23 & & \\
\hline P-Value & 0.0000 & 0.0000 & & \\
\hline \multicolumn{3}{|l|}{$\begin{array}{l}\text { Instrument F-test } \\
(2,105146) /(2,105068)\end{array}$} & 3115.81 & 3113.5 \\
\hline \multicolumn{3}{|l|}{ P-Value } & \multicolumn{2}{|c|}{${ }^{* * *}$ indicates statistically significant at 1 percent level, ${ }^{* *}$ at 5 percent level, ${ }^{*}$ at 10 percent level. } \\
\hline \multicolumn{5}{|l|}{ Notes: } \\
\hline \multicolumn{5}{|c|}{ (a) Information about congressional committee assignment and years of service comes from http://clerk.house.gov/. } \\
\hline \multicolumn{5}{|c|}{ We match this to census tract geography using the Mable/Geocorr database online at } \\
\hline \multicolumn{5}{|c|}{ http://mcdc2.missouri.edu/websas/geocorr90.shtml } \\
\hline \multicolumn{5}{|c|}{ (b) Unit of observation is the two digit SIC industry at the census tract level of geography. } \\
\hline (c) We also run the first stage by clusterin & tandard errors & e SIC 2 digit & this decreases & tandard errors \\
\hline
\end{tabular}


Table 6: Instrumental Variable Estimates for Effect of Tax Incentives on Establishment Location, Standard Errors Clustered at the City Level Shown in Parenthesis

\begin{tabular}{|c|c|c|c|c|c|c|c|}
\hline $\begin{array}{l}\text { Short } \\
\text { Term }\end{array}$ & Construction & Manufacturing & Transportation & Wholesale & Retail & FIRE & Service \\
\hline Constant & $\begin{array}{l}-0.000952 \\
(0.001552)\end{array}$ & $\begin{array}{l}-0.000743^{\star *} \\
(0.000319)\end{array}$ & $\begin{array}{l}0.00023 \\
(0.0006)\end{array}$ & $\begin{array}{l}-0.00726^{\star *} \\
(0.003579)\end{array}$ & $\begin{array}{c}-0.00476^{\star * *} \\
(0.00135)\end{array}$ & $\begin{array}{l}0.002853^{* *} \\
(0.001125)\end{array}$ & $\begin{array}{l}-0.000299 \\
(0.000522)\end{array}$ \\
\hline$E Z$ & $\begin{array}{c}-0.004331^{*} \\
(0.00266)\end{array}$ & $\begin{array}{l}0.001363^{\star *} \\
(0.000633)\end{array}$ & $\begin{array}{c}-0.006419^{* * *} \\
(0.001274)\end{array}$ & $\begin{array}{l}0.022578^{*} \\
(0.012452)\end{array}$ & $\begin{array}{l}0.004913^{* *} \\
(0.002061)\end{array}$ & $\begin{array}{l}-0.01015^{\star * *} \\
(0.002704)\end{array}$ & $\begin{array}{c}0.002307 \\
(0.002011)\end{array}$ \\
\hline $\begin{array}{c}\mathrm{N} \\
\mathrm{R}^{2} \\
\\
\text { Long } \\
\text { Term }\end{array}$ & $\begin{array}{c}3,993 \\
0.01\end{array}$ & $\begin{array}{c}26,620 \\
0.01\end{array}$ & $\begin{array}{c}11,979 \\
0.01\end{array}$ & $\begin{array}{c}2,662 \\
0.02\end{array}$ & $\begin{array}{c}10,648 \\
0.02\end{array}$ & $\begin{array}{c}9,317 \\
0.01\end{array}$ & $\begin{array}{c}18,634 \\
0.02\end{array}$ \\
\hline Constant & $\begin{array}{l}-0.000668 \\
(0.001672)\end{array}$ & $\begin{array}{l}-0.000852^{* *} \\
(0.000361)\end{array}$ & $\begin{array}{c}0.00085 \\
(0.000805)\end{array}$ & $\begin{array}{l}-0.005497 \\
(0.003222)\end{array}$ & $\begin{array}{c}-0.00424^{\star * *} \\
(0.001392)\end{array}$ & $\begin{array}{r}-0.001205 \\
(0.00113)\end{array}$ & $\begin{array}{c}0.000724 \\
(0.000563)\end{array}$ \\
\hline$E Z$ & $\begin{array}{l}-0.004949 \\
(0.003188)\end{array}$ & $\begin{array}{c}0.001611^{* * *} \\
(0.000573)\end{array}$ & $\begin{array}{c}-0.007862^{\star \star \star} \\
(0.002091)\end{array}$ & $\begin{array}{l}0.019034^{*} \\
(0.010945)\end{array}$ & $\begin{array}{c}0.000802 \\
(0.002141)\end{array}$ & $\begin{array}{c}0.008212^{\star \star \star} \\
(0.002768)\end{array}$ & $\begin{array}{l}-0.003315 \\
(0.003315)\end{array}$ \\
\hline $\mathrm{N}$ & 3,993 & 26,620 & 11,979 & 2,662 & 10,648 & 9,317 & 18,634 \\
\hline $\mathrm{R}^{2}$ & 0.01 & 0.01 & 0.01 & 0.13 & 0.03 & 0.01 & 0.13 \\
\hline
\end{tabular}
Notes:

(a) The pre-treatment year is 1994, the treatment year is 1996.

(b) Unit of observation is the two digit SIC industry at the census tract level of geography.

(c) Data on the number of firms in a given industry is from the Dunn \& Bradstreet survey and is differenced to reflect our identification strategy.

(d) The EZ variable represents designation of the federal Empowerment Zone wage tax credit at the census tract level, the coefficient on this variable reflects the effect of this tax incentive on the share of business establishments that locate in the area relative to the surrounding city compared to areas that applied for the EZ designation but were denied relative to their respective surrounding city. 
Table 7: Instrumental Variable Estimates for Effect of Tax Incentives on Employment at Zone Establishments, Standard Errors Clustered at the City Level Shown in Parenthesis

\begin{tabular}{|c|c|c|c|c|c|c|c|}
\hline $\begin{array}{l}\text { Short } \\
\text { Term }\end{array}$ & Construction & Manufacturing & Transportation & Wholesale & Retail & FIRE & Service \\
\hline Constant & $\begin{array}{c}-0.00359 \\
(0.002507)\end{array}$ & $\begin{array}{l}-0.002468^{*} \\
(0.001338)\end{array}$ & $\begin{array}{c}0.000814 \\
(0.002801)\end{array}$ & $\begin{array}{l}-0.001198 \\
(0.003244)\end{array}$ & $\begin{array}{l}-0.001363 \\
(0.001918)\end{array}$ & $\begin{array}{c}0.001449 \\
(0.001473)\end{array}$ & $\begin{array}{l}0.000639 \\
(0.00068)\end{array}$ \\
\hline EZ & $\begin{array}{l}-0.008633 \\
(0.009202)\end{array}$ & $\begin{array}{l}0.002921^{* *} \\
(0.001347)\end{array}$ & $\begin{array}{l}-0.006288^{*} \\
(0.003523)\end{array}$ & $\begin{array}{l}-0.002313 \\
(0.008837)\end{array}$ & $\begin{array}{l}-0.002845 \\
(0.005686)\end{array}$ & $\begin{array}{c}0.004272 \\
(0.005608)\end{array}$ & $\begin{array}{c}-0.003584 \\
(0.002733)\end{array}$ \\
\hline $\begin{array}{c}\mathrm{N} \\
\mathrm{R}^{2} \\
\\
\text { Long } \\
\text { Term }\end{array}$ & $\begin{array}{c}3,993 \\
0.01\end{array}$ & $\begin{array}{c}26,620 \\
0.01\end{array}$ & $\begin{array}{c}11,979 \\
0.01\end{array}$ & $\begin{array}{c}2,662 \\
0.01\end{array}$ & $\begin{array}{c}10,648 \\
0.01\end{array}$ & $\begin{array}{c}9,317 \\
0.01\end{array}$ & $\begin{array}{c}18,634 \\
0.01\end{array}$ \\
\hline Constant & $\begin{array}{l}-0.003679 \\
(0.002672)\end{array}$ & $\begin{array}{l}-0.00276^{\star *} \\
(0.001339)\end{array}$ & $\begin{array}{c}0.001688 \\
(0.002794)\end{array}$ & $\begin{array}{c}0.000845 \\
(0.003728)\end{array}$ & $\begin{array}{r}-0.002595 \\
(0.00181)\end{array}$ & $\begin{array}{l}-0.001298 \\
(0.001981)\end{array}$ & $\begin{array}{c}0.001259 \\
(0.001093)\end{array}$ \\
\hline$E Z$ & $\begin{array}{l}-0.009475 \\
(0.009119)\end{array}$ & $\begin{array}{l}0.003718^{\star *} \\
(0.001726)\end{array}$ & $\begin{array}{l}-0.007267 \\
(0.005283)\end{array}$ & $\begin{array}{c}-0.00116 \\
(0.011145)\end{array}$ & $\begin{array}{c}0.002635 \\
(0.002671)\end{array}$ & $\begin{array}{c}0.009708 \\
(0.007105)\end{array}$ & $\begin{array}{l}-0.006127 \\
(0.004676)\end{array}$ \\
\hline $\mathrm{N}$ & 3,993 & 26,620 & 11,979 & 2,662 & 10,648 & 9,317 & 18,634 \\
\hline $\mathrm{R}^{2}$ & 0.01 & 0.01 & 0.01 & 0.02 & 0.01 & 0.01 & 0.01 \\
\hline
\end{tabular}

Notes:

(a) The pre-treatment year is 1994, the treatment year is 1996.

(b) Unit of observation is the two digit SIC industry at the census tract level of geography.

(c) Data on the employment at establishments in a given industry is from the Dunn \& Bradstreet survey and is differenced to reflect our identification strategy.

(d) The EZ variable represents designation of the federal Empowerment Zone wage tax credit at the census tract level, the coefficient on this variable reflects the effect of this tax incentive on the share of business establishments that locate in the area relative to the surrounding city compared to areas that applied for the EZ designation but were denied relative to their respective surrounding city. 
Table 8: Instrumental Variables Results for Effect of Tax Incentives by Quartile Value of $\alpha$, Standard Errors Clustered at the City Level Shown in Parenthesis

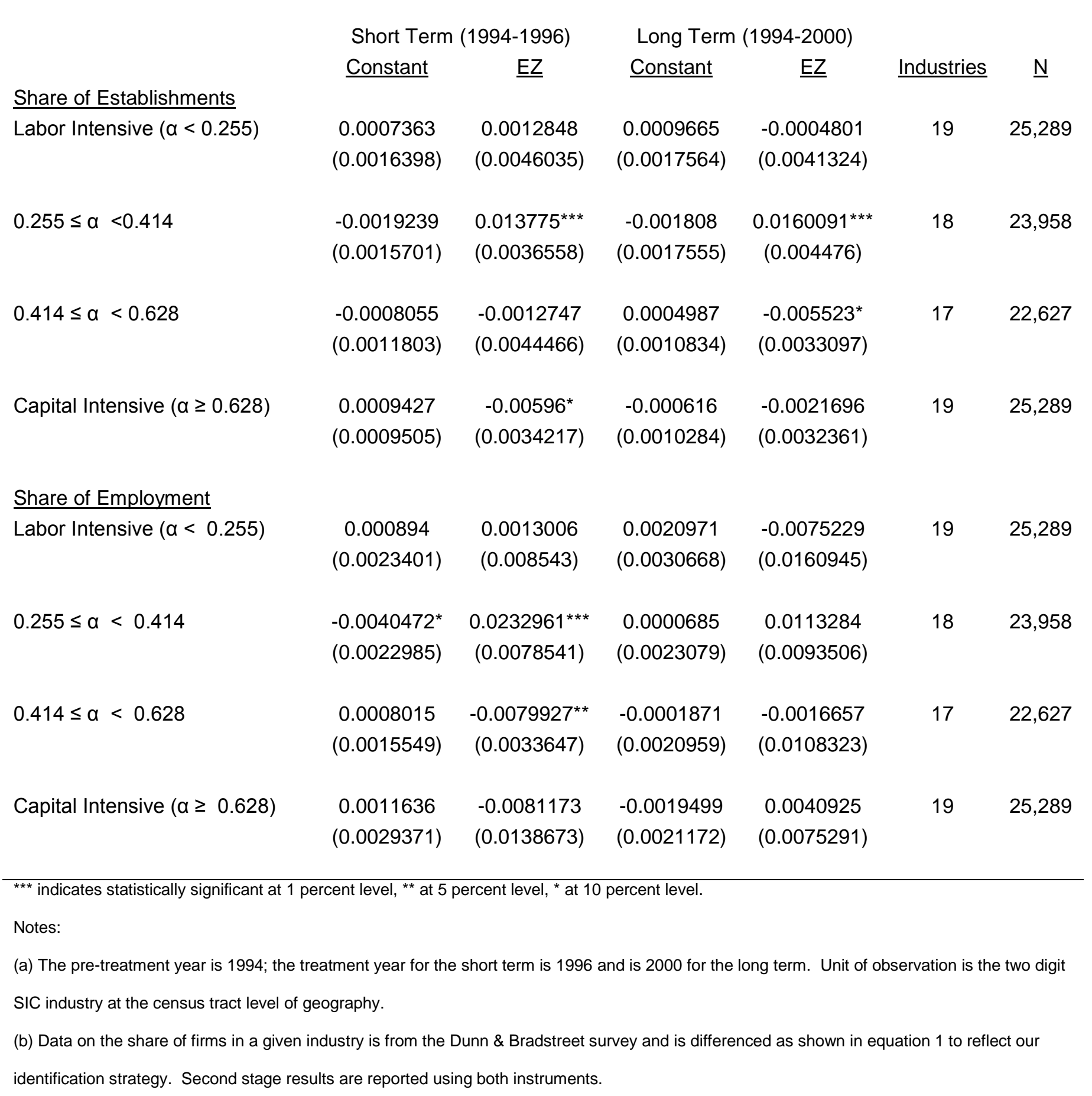


Figure 1: Predicted Change from Empowerment Zone Wage Tax Credit by Value of Alpha for Equlibrium Labor and Reduction in Total Cost

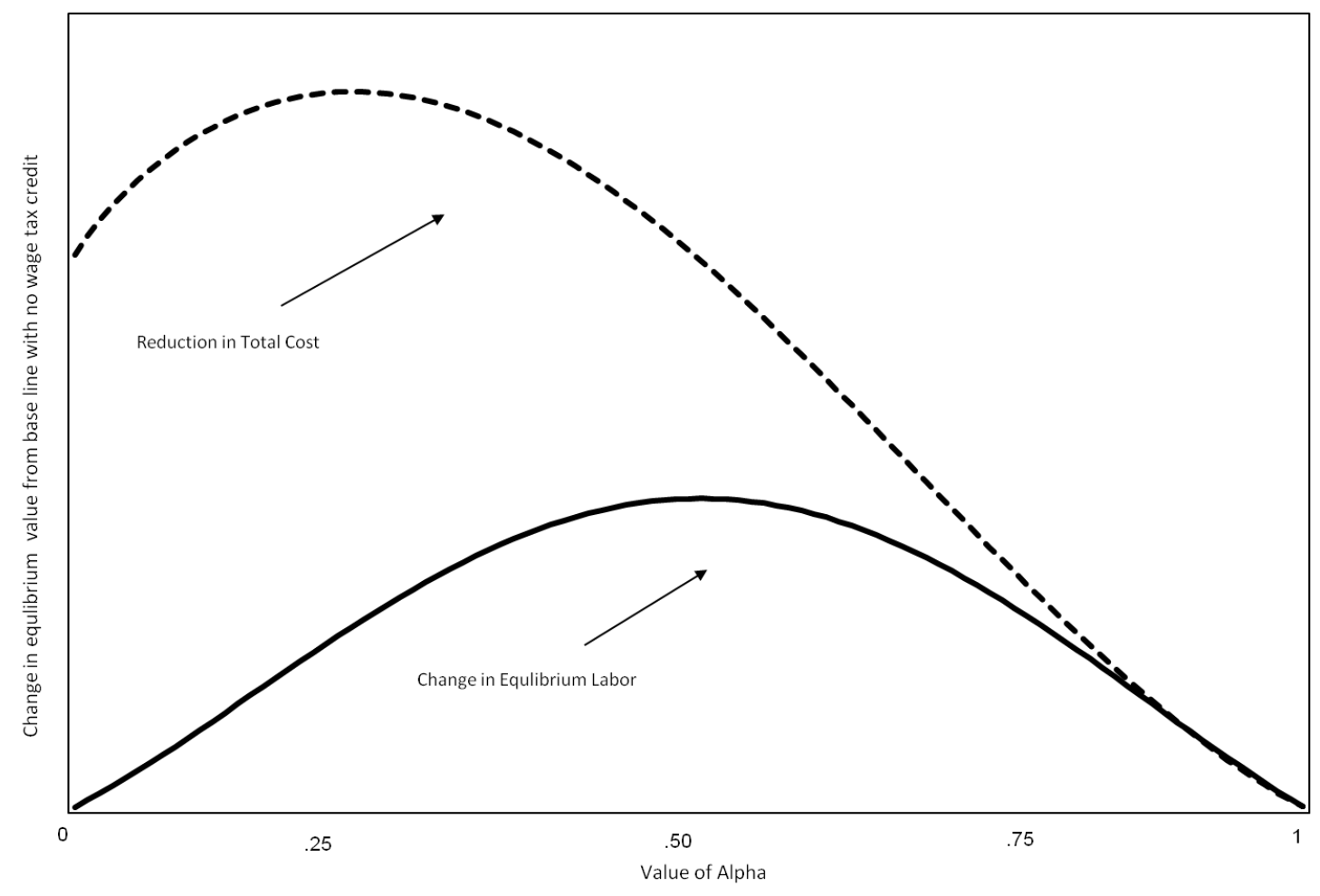

Source: Authors calculations assuming constant values of w, r, x, A, with a 20 percent wage tax credit 